\title{
INITIAL SCREENING OF HERBICIDES TOLERATED BY NATIVE PLANTS
}

\author{
K.C. HARRINGTON and H.K. SCHMITZ \\ Institute of Natural Resources, Massey University, Palmerston North, \\ New Zealand \\ Corresponding author: K.Harrington@massey.ac.nz
}

\begin{abstract}
During the establishment of native plants in revegetation projects, the plants often need to be released from weed competition, but little is known of their tolerance of herbicides suitable for release spraying. Ten native species were treated as 8-month-old plants in planter bags with eight herbicides at rates suitable to control weeds. Clopyralid, fluazifop and haloxyfop could probably control weeds selectively around Coprosma robusta, Hebe stricta, Pittosporum tenuiflorum, Carex flagellifera, Phormium cookianum and Leptospermum scoparium. Clopyralid was not tolerated by Fuchsia excortica, which was the most sensitive species to many of the herbicides evaluated. However, this species showed good tolerance to haloxyfop, fluazifop and terbuthylazine. Although Plagianthus regius was also damaged by clopyralid, it tolerated metsulfuron and terbuthylazine. The two grasses evaluated, Poa cita and Chionochloa flavicans, tolerated clopyralid and aminopyralid well, but were severely damaged by haloxyfop, fluazifop and terbuthylazine.

Keywords: herbicide tolerance, native plants, revegetation, amitrole, aminopyralid, clopyralid, haloxyfop, metsulfuron, glyphosate, terbuthylazine.
\end{abstract}

\section{INTRODUCTION}

Native plant species are often planted as part of revegetation projects, generally using plants grown initially in planter bags at nurseries then transplanted out to revegetation sites (Porteous 1993). Following transplanting, weed species often compete with establishing native plants, which can result in severe stunting or plant death.

When forestry species are planted, young trees are commonly released from competition during the first year of growth using herbicides such as haloxyfop, clopyralid and terbuthylazine applied directly over the trees (Davenhill et al. 1997). With revegetation projects, the only use of herbicide is generally careful application of non-selective herbicides such as paraquat and glyphosate around the plants with shielded nozzles (Porteous 1993). Application of herbicides directly over the establishing plants would be faster but is usually not possible due to lack of information about the tolerance of these native species to suitable herbicides.

The objective of this pot trial was to assess the potential safety of herbicides suitable for releasing native plant species from weed competition.

\section{MATERIALS AND METHODS}

Plants of ten native species (Table 1) were established in a bark-based potting mix in planter bags (PB 3) at a commercial nursery. After 8 months (or 14 months for Hebe stricta), the plants were transported to the Plant Growth Unit of Massey University (Palmerston North) and placed in a standing out area on black weed mat where they were subjected to daily overhead watering to supplement natural rainfall. Prior to treatment, the Poa cita foliage was trimmed from a length of $70-80 \mathrm{~cm}$ back to $30-40 \mathrm{~cm}$, and 
the Carex flagellifera from 100-120 $\mathrm{cm}$ back to $40 \mathrm{~cm}$. Four of the species, Coprosma robusta, H. stricta, Pittosporum tenuiflorum and Plagianthus regius were located under shade cloth to stop them falling over in the wind.

TABLE 1: The species tested for tolerance of herbicides, with average height of the plants when herbicides were applied.

\begin{tabular}{lllc}
\hline Common name & Botanical name & Family name & $\begin{array}{c}\text { Height when } \\
\text { treated }(\mathrm{cm})\end{array}$ \\
\hline broad-leaved snow tussock & Chionochloa flavicans & Poaceae & $20-30 \mathrm{~cm}$ \\
karamu & Coprosma robusta & Rubiaceae & $50-90 \mathrm{~cm}$ \\
koromiko & Hebe stricta & Plantaginaceae & $80-90 \mathrm{~cm}$ \\
manuka & Leptospermum scoparium & Myrtaceae & $70-90 \mathrm{~cm}$ \\
matipo & Pittosporum tenuiflorum & Pittosporaceae & $60-90 \mathrm{~cm}$ \\
mountain flax & Phormium cookianum & Agavaceae & $50-60 \mathrm{~cm}$ \\
ribbonwood & Plagianthus regius & Malvaceae & $80-120 \mathrm{~cm}$ \\
silver tussock & Poa cita & Poaceae & $30-35 \mathrm{~cm}^{1}$ \\
tree fuchsia & Fuchsia excorticata & Onagraceae & $30-60 \mathrm{~cm}$ \\
weeping brown sedge & Carex flagellifera & Cyperaceae & $40 \mathrm{~cm}^{1}$ \\
\hline
\end{tabular}

${ }^{1}$ Trimmed to this height prior to treatment.

On 18 December 2006, herbicides listed in Table 2 were sprayed to run-off over plants of each species using a hand-held sprayer, and also to the top of potting mixture for each plant. Glyphosate was not applied to either of the grass species due to insufficient plants being available to apply every treatment. Fluazifop was the only herbicide for which surfactant was added (Contact at $1.5 \mathrm{ml} /$ litre). A randomised block design was used with four replicates (plants blocked depending on their vigour immediately prior to treatment), with an untreated control for each species. A scoring system $(0=$ very healthy, 10 = plant death) was used to quantify the apparent health of the plants every 2 weeks for 12 weeks after treatment. The average daily temperature during the 12 weeks of assessment ranged from $11.6-22.6^{\circ} \mathrm{C}$.

Data were subjected to an analysis of variance for each species, and least significant differences calculated where treatment differences were significant.

TABLE 2: The herbicides and rates applied to the species listed in Table 1.

\begin{tabular}{llc}
\hline Active ingredient & Trade name & g ai/100 litres \\
\hline aminopyralid & Tordon Max & 9.0 \\
amitrole & Amitrole ATA & 400 \\
clopyralid & Versatill & 45 \\
fluazifop & Fusilade & 75 \\
glyphosate & Roundup Transorb & 270 \\
haloxyfop & Gallant & 30 \\
metsulfuron & Escort & 6.0 \\
terbuthylazine & Gardoprim & 600 \\
\hline
\end{tabular}




\section{RESULTS AND DISCUSSION}

As expected, the two grasses assessed, $P$. cita and $C$. flavicans, were badly damaged by haloxyfop and fluazifop (Table 3 ). Likewise, terbuthylazine was very damaging to these species. Herbicides suitable for broad-leaved weed control that were tolerated by these tussock species included clopyralid, aminopyralid and amitrole. Further trials could be conducted to assess whether amitrole or metsulfuron could remove grass weeds selectively from $P$. cita or C. flavicans,

Haloxyfop and fluazifop were generally tolerated well by the other eight plant species (Tables 3 and 4), allowing these to be used for grass weed control if necessary. With all treatments assessed in this trial, further testing is required under field conditions as the plants were over 8 months old and growing in confined rooting zones. The tolerance of $P$. regius to haloxyfop and fluazifop particularly needs further testing before recommendations can be made on their safety.

A number of herbicides looked promising for controlling weeds selectively in C. flagellifera and P. cookianum, although metsulfuron was damaging to P. cookianum, and neither glyphosate nor amitrole appear safe for $C$. flagellifera. The tolerance of glyphosate by $P$. cookianum is worth further study, although $P$. cookianum was not growing actively during the study, possibly because of root constriction by the planter bags, and thus results should be treated with caution.

The F. excorticata appeared the most sensitive to herbicides of the ten species investigated, although even untreated plants were not very healthy. Clopyralid was tolerated by most species, but it could not be recommended near $F$. excorticata. Terbuthylazine was the herbicide most worthy of further study with this species.

TABLE 3: The health (scores ranging from $0=$ very healthy to $10=$ dead) of four native monocotyledons and Fuchsia excorticata 12 weeks after spraying to run-off with herbicide treatments.

\begin{tabular}{lccccc}
\hline & $\begin{array}{c}\text { Chionochloa } \\
\text { flavicans }\end{array}$ & $\begin{array}{c}\text { Poa } \\
\text { cita }\end{array}$ & $\begin{array}{c}\text { Carex } \\
\text { flagellifera }\end{array}$ & $\begin{array}{c}\text { Phormium } \\
\text { cookianum }\end{array}$ & $\begin{array}{c}\text { Fuchsia } \\
\text { excorticata }\end{array}$ \\
\hline aminopyralid & 3.8 & 3.5 & 4.5 & 4.0 & 10.0 \\
amitrole & 3.8 & 4.5 & 7.7 & 4.8 & 8.8 \\
clopyralid & 4.0 & 3.0 & 4.3 & 3.5 & 10.0 \\
fluazifop & 7.8 & 8.0 & 4.0 & 3.8 & 5.5 \\
glyphosate & - & - & 8.0 & 3.3 & 8.3 \\
haloxyfop & 8.8 & 10.0 & 4.5 & 3.5 & 5.3 \\
metsulfuron & 4.8 & 3.8 & 5.3 & 7.8 & 10.0 \\
terbuthylazine & 9.0 & 10.0 & 5.8 & 4.0 & 5.3 \\
untreated & 3.3 & 3.0 & 3.8 & 3.3 & 5.5 \\
LSD (P<0.05) & 1.2 & 1.4 & 1.5 & 1.2 & 2.3 \\
\hline
\end{tabular}

As with $F$. excorticata, $P$. regius was quite sensitive to many of the herbicides tested, yet terbuthylazine appeared to be tolerated well, with treated plants appearing healthier than untreated plants from about 8 weeks after treatment (Table 4).

For C. robusta, H. stricta, L. scoparium and P. tenuiflorum, clopyralid mixed with either haloxyfop or fluazifop would appear to be suitable for controlling existing weeds, while terbuthylazine would also be suitable for weed knockdown and residual protection in all but $H$. stricta. Aminopyralid and glyphosate also showed some potential with these 
species. Because herbicides were applied to run-off over all foliage of these plants, there is good potential to use herbicides such as glyphosate for spraying around the base of species that were not badly damaged by the overall treatment.

Although field testing will be required before firm recommendations can be given, these results have indicated which herbicides are worth focusing on with such field tests.

TABLE 4: The health (scores ranging from $0=$ very healthy to $10=$ dead) of five native shrub species 12 weeks after spraying to run-off with herbicide treatments.

\begin{tabular}{lccccc}
\hline & $\begin{array}{c}\text { Coprosma } \\
\text { robusta }\end{array}$ & $\begin{array}{c}\text { Hebe } \\
\text { stricta }\end{array}$ & $\begin{array}{c}\text { Leptospermum } \\
\text { scoparium }\end{array}$ & $\begin{array}{c}\text { Pittosporum } \\
\text { tenuiflorum }\end{array}$ & $\begin{array}{c}\text { Plagianthus } \\
\text { regius }\end{array}$ \\
\hline aminopyralid & 4.8 & 4.3 & 4.3 & 4.0 & 10.0 \\
amitrole & 4.3 & 6.5 & 8.5 & 6.8 & 9.0 \\
clopyralid & 2.8 & 3.0 & 4.0 & 3.5 & 6.3 \\
fluazifop & 2.8 & 3.3 & 3.5 & 2.8 & 5.8 \\
glyphosate & 5.8 & 7.0 & 4.0 & 4.0 & 6.3 \\
haloxyfop & 2.8 & 3.0 & 3.5 & 2.8 & 5.0 \\
metsulfuron & 7.0 & 6.5 & 6.3 & 9.0 & 4.8 \\
terbuthylazine & 4.0 & 5.8 & 3.0 & 3.5 & 2.8 \\
untreated & 2.8 & 3.5 & 3.3 & 3.5 & 4.0 \\
LSD $(\mathrm{P}<0.05)$ & 0.68 & 1.3 & 1.1 & 1.1 & 1.3 \\
\hline
\end{tabular}

\section{ACKNOWLEDGEMENTS}

We would like to thank Robert Coulson of Rural Supply Technologies Ltd for funding the research, and also the staff of Massey University's Plant Growth Unit and Whitney Harrington for technical assistance.

\section{REFERENCES}

Davenhill NA, Ray JW, Vanner AL 1997. Forest weed control manual. New Zealand Forest Research Institute, Rotorua, New Zealand. $136 \mathrm{pp}$.

Porteous T 1993. Native forest restoration: a practical guide for landowners. Queen Elizabeth II National Trust, Wellington, New Zealand. 184 pp. 